[Agr. Biol. Chem., Vol. 30, No. 10, p. 962 966, 1966]

\title{
Pentose Metabolism by Candida utilis
}

\author{
Part III. Polyol: NAD Oxidoreductase \\ By Hiroyuki Honitsu and Mikio Tomoeda \\ Department of Agricultural Chemistry, Gifu University, Gifu \\ Received March 12, 1966
}

\begin{abstract}
Extract of Candida utilis contains polyol: NAD oxidoreductase which catalyzes the conversion of polyols to the corresponding ketoses.

By fractionation with ammonium sulfate and on DEAE-cellulose column chromatography, the purity of enzyme has been increased about 14-fold.

The relatively high activity with both xylitol and sorbitol suggests that they may be the natural substances for the enzyme.

Evidence suggests that this enzyme relates to the metabolism of $\mathrm{D}$-xylose in Candida utilis.
\end{abstract}

\section{INTRODUCTION}

Though the oxidation of polyhydric alcohols to ketoses in Acetobacter xylinum was discovered by Bertrand," it had not been known about the enzyme on this reaction until Blakley ${ }^{2}$ discovered polyol: NAD oxidoreductase which catalyzes such a reaction.

But, recently, a number of polyol NAD: oxidoreductase have been described in bacteria species and guinea pig liver. ${ }^{3}$

The presence of the enzyme in Acetobacter suboxydans and Candida utilis was described by Arcus and Edson, ${ }^{4}$ or Chakravorty et al. ${ }^{5}$ )

Xylose metabolism in Candida utilis was clarified by Chakravorty et al. ${ }^{5}$ who described the absence of xylose ketol-isomerase and xylose being metabolized via only xylitol by polyol NAD: oxidoreductase system.

\footnotetext{
Abbreviations used: DEAE, diethylaminoethyl-; EDTA, ethylenediamine tetra acetate; NAD, nicotinamide adenine dinucleotide; NADP, nicotinamide adenine dinucleotide phosphate; $\mathrm{NADH}_{2}$, nicotinamide adenine dinucleotide reduced; $p$-CMB, $p$-chloromercuribenzoate.

1) G. Bertrand, Compt. rend. Acad. Sci., 126, 762 (1898).

2) R. L. Blakley, Biochem. J., 49, 257 (1951).

3) S. Hollman and O. Touster, J. Am. Chem. Soc., 78, 3544 (1956).

4) A.C. Arcus N. L. Edson, Biochem. J., 64, 385 (1956).

5) M. Chakravorty et al., J. Biol. Chem., 237, 1014 (1962).
}

But, in our previous paper, ${ }^{6)}$ it was clarified that in Candida utilis xylose is metabolized via xylulose by xylose ketol-isomerase.

In this paper, it is revealed that in addition to this system, which includes xylose ketolisomerase system, xylose is also metabolized via xylitol by polyol NAD: oxidoreductase as shown in the report by Chakravorty. ${ }^{5)}$

\section{MATERIALS AND METHODS}

Materials. The following chemicals were obtained from commercial sources: NAD, NADP, D-sorbitol, $\mathrm{D}$-fructose, inositol and D-mannitol. D-Xylitol, Dribitol and L-arabitol were prepared by reduction of the corresponding aldoses with $\mathrm{NaBH}_{4} . \mathrm{NADH}_{2}$ was prepared by chemical reduction of NAD with sodium dithionite. Conditions for growth of Candida utilis No. 8 and preparation of cell-free extracts were essentially the same as described previously.6)

Assay. Polyol NAD: oxidoreductase activity was measured as the rate of reduction of NAD by the following method: the incubation mixture contained $0.15 \mathrm{M}$ phosphate buffer, $\mathrm{pH} 9.0,0.3 \mathrm{mM} \mathrm{NAD}, 0.03 \mathrm{M}$ xylitol or other polyols, and diluted enzyme. The reaction was started by addition of substrate and followed for up to 10 minutes. A unit of the enzyme, was defined as the quantity required to produce a

6) M. Tomoeda and H. Horitsu, This Journal., 28; 139. (1964). 
change in optical density of 0.01 per minute at $340 \mathrm{~m} \mu$.

- Specific activity was expressed as units per mg protein. Protein was determined with Folin-Ciocalteu reagent. ${ }^{7)}$

Unless otherwise stated, enzyme activity was measured with xylitol as substrate used.

\section{RESULTS}

Purification Procedure. The cell-free extracts were brought to $30 \%$ saturation with solid ammonium sulfate and allowed to stand at $0 \sim 3^{\circ} \mathrm{C}$ for ten minutes. After removal of the precipitate, the supernatant solution was brought to $50 \%$ saturation with ammonium sulfate. The precipitate between 30 and $50 \%$ saturation was dissolved in water and dialyzed against distilled water.

This fraction $(30 \sim 50 \%$ ammonium sulfate saturation) was adsorbed on a DEAE-cellulose column which had been equilibrated with 0.1 m phosphate buffer, pH 6.0. After being washed with the buffer, the column was treated stepwise with $0.1 \mathrm{~m}$ phosphate buffer, pH 7.0 containing $0.1 \mathrm{~m} \mathrm{KCl}, 0.1 \mathrm{~m}$ phosphate buffer, pH 9.0 containing $0.1 \mathrm{M} \mathrm{KCl,} 0.1 \mathrm{M}$ phosphate buffer, pH 9.0 containing $0.2 \mathrm{M} \mathrm{KCl}$ and $0.1 \mathrm{M}$ phosphate buffer, $\mathrm{pH} 9.0$ containing $0.4 \mathrm{M} \mathrm{KCl}$.

The eluation pattern is shown in Fig. 1. Fig. 1 shows that the enzyme activity appear's on the fraction number 3 to 10 . The results of purification experiment are summarized in Table I. The purity of enzyme is increased to about 14-fold as compared with that of crude enzyme in the crude cell-free extracts.

TABle I. PURIFICATION OF POLYOL: NAD OXIDOREDUCTASE

$\begin{array}{lrrcc}\text { Fraction } & \begin{array}{c}\text { Total } \\ \text { Protein } \\ (\mathrm{mg})\end{array} & \begin{array}{c}\text { Total } \\ \text { Units }\end{array} & \begin{array}{c}\text { Specific } \\ \text { Activity }\end{array} & \begin{array}{l}\text { Yield } \\ (\%)\end{array} \\ \text {-free extract } & 5,400 & 5,950 & 1.1 & 100 \\ \mathrm{SO}_{4}, 30 \sim 50 \% & 913 & 3,930 & 4.3 & 66 \\ \mathrm{AE}, \text { No. 3 } \sim 10 & 100 & 1,440 & 14.4 & 24\end{array}$

\section{Properties of the Enzyme}

1) Relationship between Enzyme Concentration and Enzyme Activity. In order to decide measurable range of enzyme concentration, the relationship between enzyme concentration and enzyme activity was examined. The experimental results are given in Fig. 2 :



FIG. 1. Pattern of Polyol: NAD oxidoreductase on DEAE-Cellulose Column. 


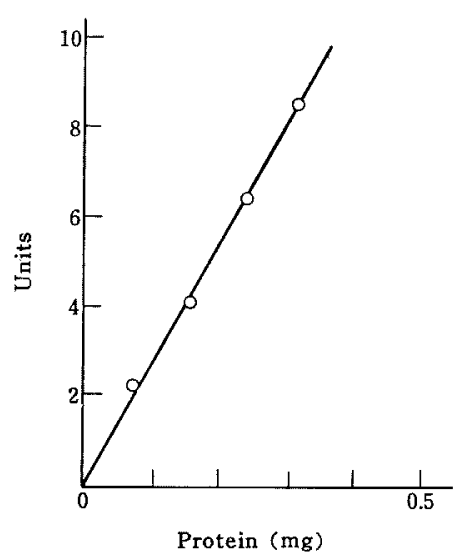

FIG. 2. Proportionality of the Enzyme to Protein Concentration.

There was a linear relationship between enzyme concentration and enzyme activity when the enzyme activity was less than 9 units.

2) Effect of pH. The rate of reaction with xylitol as substrate was maximal at $\mathrm{pH}$ 9.0. At $\mathrm{pH} 7.0$ the rate was only one-third of that observed at $\mathrm{pH} 9.0$ as shown in Fig. 3.

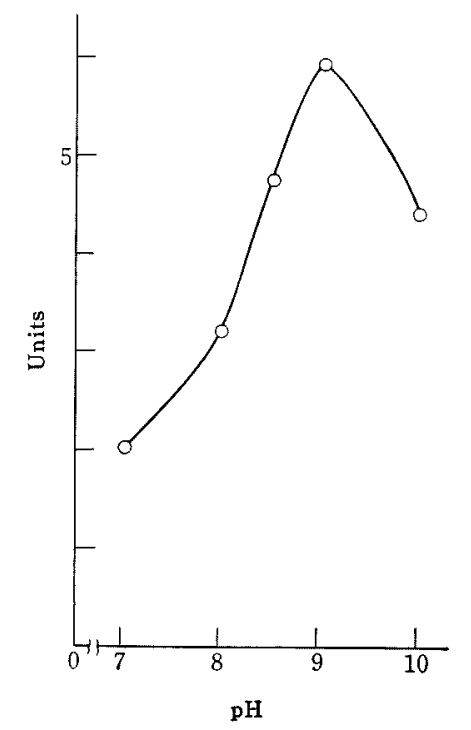

FIG. 3. Effect of $\mathrm{pH}$ on the Enzyme.
3) Substrate Specificity with Polyhydric Alcohols. The enzyme is most active with xylitol, but has relatively low specificity as shown in Table II.

TABLE II. EFFECT OF SUBstrates

$\begin{array}{lcc}\text { Substrates } & \text { Specific Activity } & \text { Relative to Xylitol } \\ \text { Xylitol } & 6.89 & 100.0 \\ \text { Sorbitol } & 3.06 & 44.4 \\ \text { L-Arabitol } & 0.64 & 9.2 \\ \text { D-Mannitol } & 0.51 & 7.4 \\ \text { D-Ribitol } & 0.00 & 0.0\end{array}$

4) Additional Effect of Sorbitol to Xylitol. Inhibitory effect by addition of sorbitol to xylitol in the case of polyol: NAD oxidoreductase was reported by Chakravorty et al.," whereas results in Table III present that there is no inhibitory effect by addition of sorbitol to xylitol on the activity of polyol: NAD oxidoreductase prepared here.

TABLE III. EFFECT OF SORBITOL ON XYLITOL

$\begin{array}{ccc}\begin{array}{c}\text { Substrate added } \\ \text { Xylitol (M) }\end{array} & \text { Sorbitol (M) } & \begin{array}{c}\text { Relative Activity } \\ (\%)\end{array} \\ 3 \times 10^{-2} & - & 100.0 \\ " & 1 \times 10^{-4} & 100.0 \\ " & 2.5 \times 10^{-4} & 122.1 \\ " & 2.5 \times 10^{-3} & 122.9 \\ " & 1 \times 10^{-2} & 130.7 \\ " & 5 \times 10^{-2} & 135.7\end{array}$

5) Effect of Metal Ions on the Enzyme. It is revealed that both $\mathrm{Mg}^{++}$and $\mathrm{Mn}^{++}$ions give some inhibitory action as shown in Table IV.

TABLE IV. EFFECT OF METAL IONS

$\begin{array}{ccc}\text { Metal Ion }\left(10^{-3} \mathrm{M}\right) & \text { Units } & \text { Relative Activity } \\ \text { None----- } & 7.0 & 100 \\ \mathrm{MgCl}_{2}---- & 6.4 & 91 \\ \mathrm{MnCl}_{2}---- & 6.6 & 93\end{array}$

6) Effect of Inhibitors. On the enzyme, the effect of several inhibitors was examined. The result is summarized in Table V Inhibition is expressed as percent against the case without inhibitor. As shown in Table V, among the chemicals tested, the inhibitory much effect is observed with $\mathrm{ICH}_{2} \mathrm{COOH}$, 
TABLE V. EFFECT OF INHIBITORS

$\begin{array}{lcc}\text { Inhibitor }\left(10^{-3} \mathrm{M}\right) & \text { Units } & \text { Inhibition }(\%) \\ \text { None--- } & 6.2 & 0.0 \\ p \text {-CMB- } & 1.4 & 77.4 \\ \mathrm{EDTA}---- & 5.6 & 10.7 \\ \mathrm{ICH}_{2} \mathrm{COOH}^{----} & 0.0 & 100.0 \\ \mathrm{NaF}^{-}-- & 5.0 & 19.3\end{array}$

TABLE VI, EFFECT OF CONCENTRATION OF $\mathrm{ICH}_{2} \mathrm{COOH}$

$\mathrm{ICH}_{2} \mathrm{COOH}(\mathrm{M}) \quad 0 \quad 10^{-3} \quad 5 \times 10^{-4} \quad 2 \times 10^{-4} \quad 1 \times 10^{-4}$

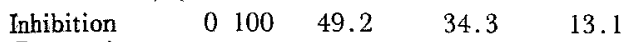

(Per cent)

p-GMB and some by NaF and EDTA. Therefore, the next experiment was carried out relating concentration of $\mathrm{ICH}_{2} \mathrm{COOH}$ with the enzyme activity and the result is shown in Table VI. The inhibition was not recovered by addition of cysteine or glutathione.

7) Effect of Coenzyme Concentration on Polyol: NAD Oxidoreductase. For this experiment, both xylitol as substrate and NAD as coenzyme were used, and effect of NAD concentration on the enzyme activity was tested. MichaelisMenten constant for NAD was calculated by the method of Lineweaver-Burk in Fig. 4. $K_{m}=5.6 \times 10^{-5} \mathrm{M}$.

8) Effect of Temperature on Reaction Velocity. Effect of temperature on the reaction rate

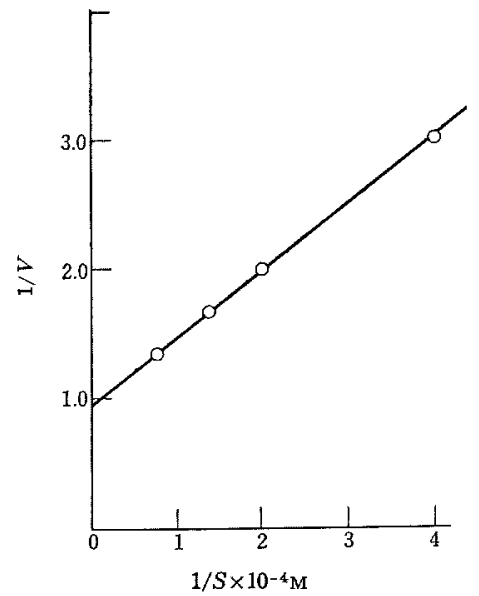

FIG. 4. Effect of NAD Concentration on the Enzyme Activity. was studied at several temperatures. In this case, enzyme activity was determined by measuring colorimetrically the formation of xylulose by cysteine-carbazole method as described in the previous paper. ${ }^{6)}$ The result is shown in Fig. 5. The activation energy of the enzyme reaction was determined by Arrhenius' equation and found to be 10,200 calories.

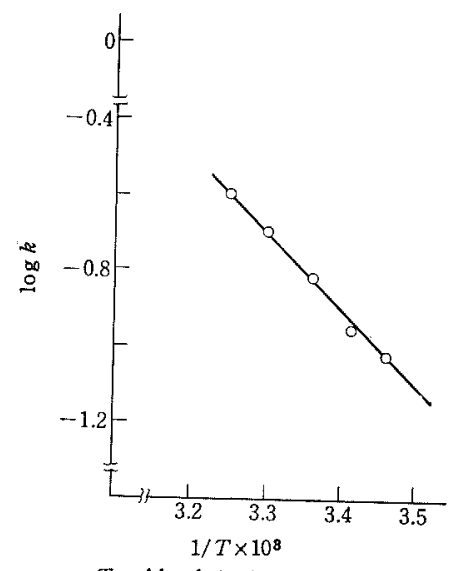

$T:$ Absolute temperature $k$ : Reaction velocity

FIG. 5. Arrhenius' Plots for the Temperature Activation of the Enzyme.

9) Effect of Coenzyme on the Enzyme Activity. Effect of substrates and coenzymes on relative activity during purification of enzyme was tested. As shown in Table VII, two polyol: NAD oxidoreductases which require the different coenzyme for their activities might be

Table VII. Relative Activity of Substrates WITH COENZYMES DURING PURIFICATION OF ENZYME

\begin{tabular}{|c|c|c|c|}
\hline \multirow{2}{*}{ Fraction } & \multirow{2}{*}{ Substrate } & \multicolumn{2}{|c|}{ Activity (units) } \\
\hline & & NAD & $\widehat{N A D P}$ \\
\hline \multirow{2}{*}{$\mathrm{Am}_{2} \mathrm{SO}_{4}, 30 \sim 50 \%$} & Xylitol & 4.3 & 4.2 \\
\hline & Sorbitol & 3.8 & 1.8 \\
\hline \multirow[t]{2}{*}{ DEAE No. $3 \sim 10$} & Xylitol & 14.4 & 0 \\
\hline & Sorbitol & 12.3 & 0 \\
\hline
\end{tabular}

Reaction mixture contained $0.15 \mathrm{M}$ phosphate buffer, $\mathrm{pH} 9.0$, $50 \mu \mathrm{g}$ of xylitol or sorbitol, $0.3 \mathrm{~mm}$ of NAD or NADP and enzyme solution as indicated. The assay conditions were' described in the text. 
contained in the extracts of Candida utilis, and might be separated to each other with DEAEcellulose column chromatography.

10) Reaction with Ketoses. Action of polyol: NAD oxidoreductase is thought to be reversible between hydric alcohols and ketoses; therefore, ketoses were allowed to react with $\mathrm{NADH}_{2}$. For the enzyme activity, decrease of ketoses by cysteine-carbazole method was used. The result is shown in Table VIII, which shows in both cases ketoses decrease.

TABLE VIII. REaction OF POLYOL: NAD OXIDOREDUCTASE WITH KETOSES

$\begin{array}{ccc}\text { Ketoses tested } & \begin{array}{c}\text { Concentration of } \\ \text { the Substrate } \\ (\mu \mathrm{g})\end{array} & \begin{array}{c}\text { Activity Decrease } \\ \text { in optical density } \\ \text { at } 520 \mathrm{~m} \mu\end{array} \\ \text { D-Fructose } & 50 & 0.16 \\ \text { D-Xylulose } & 50 & 0.05\end{array}$

Reaction mixture contained $0.15 \mathrm{M}$ phosphate buffer, $\mathrm{pH} 9.0$, $0.3 \mathrm{mM} \mathrm{NADH}$, enzyme solution and substrates as indicated. In this case, the activity was measured with the decrease in optical density at $520 \mathrm{~m} \mu$ due to the decrease of ketoses.

\section{Reaction Products}

1) Identification of the Product from Xylitol. The product obtained from xylitol by the above procedure was characterized by eluation.

The reaction mixture which was incubated with the enzyme was passed through a Dowex-1-X-8-borate column. After the reaction mixture had been adsorbed on the Dowex1-X-8-borate column, $0.01 \mathrm{~m}$ sodium borate solution was used as the first eluting solution, followed by $0.02 \mathrm{~m}$ sodium borate solution. Test of the eluting fractions with cysteinecarbazole method revealed one peak. Next, authentic $\mathrm{D}$-xylulose and L-ribulose were also adsorbed on the same column and eluted by the same solution as the above method.

As the results, authentic D-xylulose and the reaction product were both eluted by $0.01 \mathrm{M}$ sodium borate solution and authentic L-ribulose was eluted by $0.02 \mathrm{~m}$ sodium borate solution. So, the reaction product is thought to be $\mathrm{D}$ xylulose.

2) Identification of the Product Obtained from Sorbitol. The reaction mixture obtained with sorbitol was checked using paper chromato- graphy. In ascending chromatography on Toyo Filter paper No. 51 with pyridinebutanol-water mixture as the developing solvent, reaction mixture yielded a single spot of $R_{F} 0.13$, compared with a $\mathrm{D}$-fructose standard at $R_{F}$ 0.13. This means that the reaction product from sorbitol is $\mathrm{D}$-fructose.

\section{DISCUSSION}

According to the metabolism of xylose in Candida species postulated by Chakravorty et al. ${ }^{5)}$ the first step in metabolism of xylose is only the reduction of the sugar to xylitol, catalyzed by the enzyme polyol: NAD oxidoreductase. For this point, we clarified in our previous paper ${ }^{6}$ that xylose is at the first step isomerized to xylulose, catalyzed by the enzyme, xylose ketol-isomerase.

But, in the present studies, in addition to the xylose ketol-isomerase, existence of polyol: NAD oxidoreductase has been also recognized.

Further experiments are carried out on some properties of the enzyme and the following points are clarified: the polyol: NAD oxidoreductase purified from Candida utilis by our experiment is similar in its general properties to the enzyme reported by Ghakravorty et al., ${ }^{5}$ i.e., the enzyme prepared here requires NAD as coenzyme and also xylitol and sorbitol are utilized as substrate for the enzyme. But, there is difference between their results ${ }^{6}$ and our results as follows: in their results, addition of sorbitol to xylitol as substrate causes the inhibitory effect to the enzyme activity, but in our experiment, addition of sorbitol to xylitol as substrate gives promoting effect, not inhibitory effect to the enzyme activity. And inhibitory effect with EDTA on the enzyme activity is observed by their result, but such a inhibition is not observed by our studies and inhibitory effect with $p$-CBM or $\mathrm{ICH}_{2} \mathrm{COOH}$ is observed by our studies.

Acknowledgments. The authors are indebted to Mr. K. Awano and Mr. S. Yagi for their assistance and also to Dr. M. Miwa and Mr. T. Kihara, Toyo Spinning Co., for their helps. 